Efektor, Volume 6 Issue 1, 2019, Pages 7 - 13

Available online at: http://ojs.unpkediri.ac.id/index.php/efektor-e

DOI: https://doi.org/10.29407/e.v6i1.12590

\title{
Tokoh Amelia Sebagai Teladan untuk Siswa Perempuan Pendidikan Dasar
}

(Kajian Literasi Moral dalam Novel Amelia Karya Tere Liye)

\author{
Akhmad Idris ${ }^{1}$, Darni ${ }^{1}$ \\ Akhmadidris9@gmail.com \\ ${ }_{1}^{1}$ Pascasarjana Universitas Negeri Surabaya, Surabaya, Indonesia
}

\begin{abstract}
Education holds a central role in the formation of the character's protégé. Through educational institutions are expected to take shape a child's intelligent and moral. Then, how if the institution was only able to give birth to a child who is smart, but not moral? This occurs because of less awareness of moral literacy. Literature as a means of teaching at the same time, the entertainer is expected to be a breakthrough to form a generation of moral literate. Amelia's character in novel Amelia by Tere Liye can be used as a role model for female students in elementary education.
\end{abstract}

Keywords: Moral Literacy, Female Students, Amelia's Character

\begin{abstract}
Abstrak
Pendidikan memegang peran sentral dalam pembentukan anak didik karakter. Melalui lembaga pendidikan diharapkan dapat membentuk kecerdasan dan moral anak. Lalu, bagaimana jika institusi itu hanya mampu melahirkan anak yang pintar, tetapi tidak bermoral? Ini terjadi karena kurang kesadaran akan literasi moral. Sastra sebagai sarana pengajaran sekaligus, penghibur diharapkan menjadi terobosan untuk membentuk generasi melek moral. Karakter Amelia dalam novel Amelia oleh Tere Liye dapat digunakan sebagai model peran bagi siswa perempuan dalam pendidikan dasar.
\end{abstract}

Kata kunci: Literasi Moral, Siswa Perempuan, Karakter Amelia

\section{PENDAHULUAN}

Pembahasan mengenai Literasi Moral dalam karya sastra perlu dilakukan sebab dilatarbelakangi oleh tiga hal, yakni 1) esensi dasar tujuan pendidikan sebagai sarana pembangun dan pengembang watak; 2) fakta sosial yang berbanding terbalik dengan tujuan pendidikan; 3) sastra sebagai penghibur sekaligus pengajar. Esensi dasar pendidikan adalah membawa misi moralitas. Hal ini sesuai dengan UU No. 20 tahun 2003 tentang sisten pendidikan nasional yang berbunyi: "pendidikan nasional berfungsi mengembangkan kemampuan dan membentuk watak serta peradaban bangsa yang bermartabat dalam rangka mencerdaskan kehidupan bangsa .......".

Poin penting dari tujuan pendidikan nasional adalah membentuk watak serta peradaban bangsa. Tolok ukur keberhasilan pendidikan adalah tingkat moralitas anak didik. Sepintar apapun anak didik namun tidak bermoral, maka sejatinya anak tersebut tidak berpendidikan. Begitu juga sebaliknya. Dalam pepatah disebutkan: Buah dari ilmu ialah budi pekerti yang baik. Maksud pepatah tersebut adalah seorang pencari ilmu (anak didik) dianggap berhasil memanen ilmu yang telah ia tanam jika berbudi pekerti yang baik. Pencari ilmu dianggap gagal panen jika tidak memiliki sopan santun dalam bertindak dan bertutur.

Hal di atas sesuai dengan bunyi sila pancasila yang kedua: kemanusiaan yang adil dan beradab. Ciri orang yang mencerminkan nilai-nilai Pancasila adalah yang bersikap adil dan beradab. 
Orang yang tidak mencerminkan nilai Pancasila berarti tidak melaksanakan dasar suatu negara. Tentu saja ini adalah $P R$ bagi penggerak-penggerak pendidikan di Indonesia, bahwa esensi dari pendidikan adalah bermoral. Tanpa moral, pendidikan bukan apa-apa.

Fakta sosial yang terjadi di Indonesia justru berbanding terbalik dengan dasar tujuan pendidikan nasional. Moral anak-anak Indonesia sedang berada di ujung tanduk. Hal ini terbukti dengan topik yang viral dalam beberapa bulan ini, yakni fenomena Kids Zaman Now. Dilansir dari akun instagram @ngakakkocak, seorang yang bernama akun Facebook Febry mengunggah foto seorang anak laki-laki yang masih di bawah umur dengan sebotol minuman keras di depannya. Selanjutnya fenomena cabe-cabean kalangan anak Sekolah Dasar. Perempuan-perempuan yang masih berada di taraf SD mengendarai satu motor untuk 4 orang yang menggunakan pakaian seksi.

Fakta yang lain adalah sebuah unggahan video dari akun instagram @ngakakkocak yang menampilkan seorang siswa berseragam pramuka sedang berjoget di depan gurunya sendiri sesuai irama lagu "Bojoku Galak". Yang lebih parah adalah joget yang dilakukan merupakan joget yang tidak etis karena seakan-akan "memantati" gurunya sendiri disertai provokasi siswa-siswa lain yang beranggapan bahwa hal tersebut wajar-wajar saja. Jika hal ini tidak ditangani dengan serius, maka di Indonesia akan benar-benar mengalami krisis moral. Permadani, dkk dari Universitas Sebelas Maret penah melakukan penelitian perilaku sopan santun Kelompok B TK Negeri Pembina Kecamatan Pringkuku tahun 2015/2016. Hasil penelitian mereka menunjukkan bahwa dari 18 anak, hanya hanya 7 anak (38.89\%) yang dinyatakan tuntas dalam berperilaku sopan santun, sedangkan 11 anak $(61,11 \%)$ dinyatakan belum tuntas.

Beranjak dari data-data di atas, dapat dinyatakan bahwa Indonesia sedang mengalami krisis moral. Hal ini perlu segera ditinjaklanjuti agar tujuan dasar pendidikan nasional tercapai. Satu di antara cara membentuk karakter seseorang yang beradab adalah membiasakan seseorang melihat, mendengar, dan merasakan nilai-nilai kebaikan. Satu di antara jalan yang bisa digunakan adalah melalui sastra. Menurut Jumadi (2012 : 63), nenek moyang memanfaatkan sastra sebagai satu di antara sumber kebenaran, di samping sumber kebenaran agama, filsafat, dan ilmu. Ketika menebang pohon, menaklukkan binatang buas, atau memikat lawan jenis. Ketika mereka menidurkan tau mendidik anak-anaknya, mereka menggunakan dongeng. Berdasarkan fakta tersebut, moral anak dapat terbentuk melalui karya sastra dengan memperhatikan nilai moral di dalam karya sastra tersebut. Pada dasarnya anak-anak menyukai hal-hal yang diceritakan dan didongengkan. Hal tersebut biasanya lebih masuk ke dalam diri anak tersebut (Syahrul, 2012 : 147). Bacaan anak-anak berpengaruh pada kejiwaan mereka setelah mereka besar nanti. Pada masa anak-anak, dari bacaan itu mereka mulai belajar. Segala hal yang telah meka pelajari dari bacaan-bacaan mereka menjadi fondasi dalam pembentukan kepribadian mereka.

Wellek dan Werren (2016 : 23) menyatakan bahwa fungsi seni harus dikaitkan dengan dulce dan utile. Dulce berarti indah, sedangkan utile berarti berguna. Sastra berfungsi menghibur sekaligus mengajarkan sesuatu. Selain sebagai pengisi waktu luang atau sekadar hobi, sastra secara bersamaan mampu mengajarkan nilai-nilai yang dibutuhkan oleh anak-anak. Misalnya dalam dongeng Si Kancil yang mengisahkan tokoh-tokoh hewan yang berbicara layaknya manusia sehingga memberikan hiburan bagi anak-anak, namun di sisi lain lewat kisah-kisah Si Kancil dapat dipetik nilai-nilai moral tertentu.

Tidak semua karya sastra berisi tentang nilai-nilai moral dan layak dikonsumsi oleh anak-anak. Beberapa karya sastra layak dikonsumsi oleh anak-anak dan beberapa karya sastra lainnya tidak layak, seperti karya Djenar Maesa Ayu yang di dalamnya terkandung unsur-unsur 18+. Satu di antara karya sastra yang penuh dengan nilai- nilai moral adalah novel Amelia karya Tere Liye. Buku ini termasuk jajaran buku yang bergelar Best Seller. Istilah Best Seller dilansir dari web Kompasiana berarti bukubuka yang paling banyak dicari orang. Buku ini adalah buku yang paling direkomendasikan dan banyak dicari oleh orang-orang terkenal. Karya Tere Liye ini terdiri atas 33 seri cerita yang penuh dengan nilainilai moral. Reviewer dari www.googreads.com, Ulil Abshar mengatakan bahwa serial Amelia sempurna untuk memahami dunia anak-anak. Ketua Komunitas Sastra Indonesia, Ahmadun Yosi Herfanda juga 
mengatakan bahwa serial Amelia menceritakan sebuah kisah yang mengharukan sekaligus penuh bersitan hikmah dan layak dikoleksi sebagai bacaan keluarga.

Literasi pada awalnya diartikan sebagai sesuatu yang berhubungan dengan buku dan menulis (Pahl \& Rowsell, 2005:11). Literasi hanya dianggap sebagai seperangkat keterampilan yang diajarkan di sekolah-sekolah. Baru-baru ini, literasi telah diakui sebagai praktik sosial. Maksudnya, literasi telah dianggap sebagai sesuatu yang dilakukan seseorang dalam kehidupan sehari-hari, di rumah, tempat kerja, dan sekolah. Pengertian tersebut berkembang menjadi literasi yang lebih general. Literasi telah berkembang ke dalam berbagai keterampilan, seperti literasi sosial, informasi, media, data, matematika, bahkan moral atau dikenal dengan literasi moral. Literasi dalam penelitian ini diartikan sebagai kesadaran, kepekaan, atau kemelekan. Jika dikaitkan dengan moral, maka maknanya menjadi kemelekan tentang moral. Kemelekan tentang moral yang terdapat dalam karya sastra terangkai secara utuh menjadi suatu cerita.

Menjadi manusia yang literate bukan proses alamiah, tetapi proses yang dikembangkan. Herman (1997: 313) menyebutkan bahwa pelaku moral menjadi literate (kemampuan atau keterampilan untuk menggunakan pengetahuannya) bukan proses organik, tetapi proses yang disengaja. Sepaham dengan Herman, Bennett (1986: 6) juga menyebutkan bahwa literasi moral tidak lahir dengan pengetahuan, tetapi dengan proses pembelajaran. Kemampuan tersebut tidak berkembang seperti kondisi fisik manusia yang tumbuh secara alamiah, tetapi kemampuan tersebut secara sengaja dikembangkan dengan memaksimalkan kompetensi yang dimiliki. Tingkat literasi moral di Indonesia tergolong kritis. Hal ini dapat dilihat dalam hal sederhana tentang membuang sampah pada tempatnya. Di jalan-jalan, di kampung, di sungai-sungai, bahkan di daerah taman kota banyak ditemukan sampahsampah yang berceceran. Dilansir dari Kompas.com tentang hasil riset Jenna $R$ Jambeck, dkk menyebutkan bahwa Indonesia berada di posisi kedua penyumbang sampah plastik ke laut setelah Tiongkok, disusul Filipina, Vietnam, dan Sri Lanka. Menurut Riset Greenaration; organisasi nonpemerintah yang selama 10 tahun telah mengikuti isu sampah, menyebutkan bahwa rerata satu orang Indonesia menghasilkan 700 kantong plastik per tahun. Di alam, kantong plastik yang tak terurai menjadi ancaman kehidupan dan ekosistem.

Cara perempuan berinteraksi berbeda dengan laki-laki. Perempuan memiliki ciri yang khas dalam menunjukkan kemampuan moral kepada individu yang lain. Hal tersebut sesuai dengan yang disampaikan oleh Carol Gilligan. la adalah satu di antara Psikolog, ahli etika, dan feminis Amerika. Gilligan (1993:62) menyebutkan bahwa perbedaan karakteristik laki-laki dan perempuan berakibat terhadap hasil interpretasi. Laki-laki mengacu pada prinsip-prinsip kesamaan hak, sedangkan perempuan mengacu pada prinsip-prinsip kepedulian. Ketika perempuan dihadapapkan terhadap satu masalah, perempuan lebih memilih menghindari kekerasan dan memunculkan kepedulian terhadap orang lain. Tindakan etis yang dilakukan oleh perempuan bertujuan agar orang lain lebih berbahagia. Hal tersebut disebabkan oleh perempuan bertindak berdasarkan kombinasi antara emosi dan hati. Gilligan menyebutnya dengan istilah etika kepedulian.

Pada tahun 2007, Tuana mengembangkan penelitiannya tentang literasi moral dengan judul Conceptualizing Moral Literacy yang diterbitkan oleh Journal Of Educational Administration. Jurnal tersebut telah terindeks di Scopus. Tuana (2007:364) menjelaskan bahwa literasi moral dapat dibentuk dengan mengembangkan tiga keterampilan, yaitu 1) kepekaan etika (ethics sensitivity), 2) kemampuan penalaran etis (ethical reasoning skills), dan 3) imajinasi moral (moral imagination). Tiga keterampilan tersebut tidak bisa dipisahkan antara satu dan yang lainnya. Semuanya berkaitan erat, misalnya kemampuan menalar etis bisa meningkatkan kemampuan kepekaan etika. Pengembangan literasi moral harus disertai pengembangan tiga keterampilan dasar tersebut. Pendapat Tuana sejalan dengan pendapat Bennett (1986: 6-9) yang menyatakan bahwa pencapaian literasi moral dapat dilakukan dengan cara menyajikan contoh-contoh kasus tentang moral, kemudian peserta didik berusaha memecahkan kasus tersebut. Sebenarnya cara yang disebitkan oleh Bennett sejalan dengan Tuana. 
Tuana memasukkan penyajian kasus ke dalam komponen kemampuan penalaran etis (ethical reasoning skills). Bennett memilih menggunakan istilah penalaran moral (moral reasoning).

Kepekaan etika menjadi keterampilan penting dalam pengembangan literasi moral. Tuana (2007:366) memasukkan tiga komponen utama dalam kepekaan etika, yakni 1) kemampuan untuk menentukan keterlibatan isu-isu etis dalam suatu situasi, 2) kesadaran intensitas moral situasi etis, dan 3) kemampuan untuk mengidentifikasi kebaikan moral atau nilai-nilai yang mendasari situasi etis. Pemahaman tentang nilai-nilai kebaikan memberikan pola pikir yang baik untuk memeriksa situasi tertentu dan menentukan apakah situasi tersebut melibatkan masalah-masalah etis atau tidak. Misalnya, setelah memahami bahwa kejujuran dan keadilan adalah karakteristik moral, maka akan menjadi lebih mudah untuk melihat bahwa kasus membeli kaset-kaset bajakan melibatkan masalah etis karena orang yang jujur tidak akan membeli barang palsu. Tidak adil menikmati sesuatu yang dibuat oleh individu/kelompok tanpa memberi kompensasi kepada mereka dan tanpa memberi sumber daya yang dibutuhkan untuk terus berkarya.

Keterampilan kedua yang harus dikembangkan dalam literasi moral adalah kemampuan penalaran etis. Tuana (2007:368) menyebutkan bahwa kemampuan penalaran etis juga mencakup tiga komponen yang berbeda. Tiga komponen tersebut adalah 1) Pemahaman tentang berbagai kerangka etis, 2) Kemampuan untuk mengidentifikasi, menilai keabsahan fakta-fakta yang relevan dengan situasi etis, dan menilai setiap kesimpulan dari fakta-fakta tersebut, dan 3) Kemampuan untuk mengidentifikasi dan mengevaluasi nilai-nilai seorang individu atau kelompok yang relevan dengan masalah etis yang dipertimbangkan. Ahli etika sering membuat tiga divisi dari kerangka etika: utilitarian atau konsekuensialis; deontologis atau tugas yang berbasis pemikiran; dan etika kebajikan. Baru-baru ini ahli etika feminis berpendapat untuk kerangka etis keempat, yaitu etika kepedulian. Berlawanan dengan konsekuensi atau tugas, etika kepedulian memandang kebutuhan dan kepentingan tertentu individu sebagai kunci untuk perilaku etis.

Keterampilan terakhir dalam pengembangan literasi moral adalah pengembangan imajinasi moral. Johnson (1993: 202) menjelaskan bahwa imajinasi moral adalah kemampuan untuk melihat secara imajinatif macam-macam kemungkinan atas tindakan dalam situasi tertentu dan untuk merancang pertolongan potensial dan merusak hal yang mungkin diakibatkan oleh situasi tertentu. Imajinasi moral merujuk pada perpaduan afektif dan proses rasional yang berkontribusi untuk imajinasi.

\section{METODE PENELITIAN}

Penelitian ini menggunakan teknik analisis isi. Secara umum analisis isi berupaya mengungkap berbagai informasi di balik data yang disajikan di media massa atau teks, sebab tidak selamanya sumber data dalam sebuah penelitian bersumber dari manusia. Analisis isi merupakan metode simbolik. Teknik analisis isi dilakukan melalui tahapan penafsiran data, menampilkan temuan, kemudian menganalisis dan membahasnya. Penggunaan analisis isi dalam penelitian ini untuk meneliti teks yang terdapat dalam novel Amelia karya Tere Liye yang berhubungan dengan literasi moral. Teori yang digunakan untuk menganalisis isi adalah teori literasi moral Nancy Tuana dan etika kepedulian Carol Gilligan.

\section{HASIL DAN PEMBAHASAN}

Amelia adalah tokoh sentral yang mengajarkan nilai-nilai moral lewat interaksinya dengan tokoh-tokoh lain dalam novel Amelia karya Tere Liye. Nilai-nilai moral tersebut dapat dijadikan oleh guru atau siswa sebagai teladan untuk menjadi siswa yang melek moral (moral literate). Amelia dalam novel tersebut dikisahkan sebagai anak perempuan yang bersekolah pada tingkat Sekolah Dasar kelas 3. Kelebihan Amelia terletak pada kepeduliannya terhadap sesama, meskipun ia seorang perempuan dan masih bersekolah kelas $3 \mathrm{SD}$. Literasi moral yang terdapat dalam novel tersebut secara garis besar terbagi menjadi tiga komponen, yakni 1) ethics sensitivity; 2) ethical reasoning skills; 3) moral imagination. 


\section{Kepekaan Etika sebagai Wujud Kepedulian terhadap Situasi Etis}

Satu di antara komponen yang harus dipenuhi agar menjadi seorang yang melek moral adalah memiliki kemampuan untuk menyadari situasi-situasi etis. Kepekaan etika yang ditunjukkan oleh Amelia di antaranya adalah kepedulian Amelia terhadap Norris, temannya. Perempuan cenderung lebih peduli terhadap situasi-situasi etis di sekitarnya. Hal tersebut terdapat pada kutipan di bawah ini

Tanpa menunggu suaraku hilang, Norris langsung bergegas meninggalkan bangkunya. Berlari-lari ke pintu kelas. Teman-teman yang lain meletakkan pulpen. Aku ikut meletakkan pulpen setelah menandai tempat mendikte terhenti.

"Kenapa kau izinkan Amel?" Maya menyikutku.

"Daripada dia buang air besar di kelas kan?" Aku nyengir.

(Liye, 2017: 85)

Kutipan di atas menunjukkan kepedulian Amelia terhadap situasi yang sedang dialami oleh Norris. Amelia menyadari bahwa buang air besar adalah hal yang sulit untuk ditahan. Tindakan yang dipilih oleh Amelia dapat dijadikan sebagai contoh dalam berhubungan dengan teman. Jika teman laki-laki cenderung tidak peduli, maka teman perempuan cenderung lebih peka terhadap sekitarnya. Kepekaan etika yang ditunjukkan Amelia merupakan wujud kepedulian terhadap sesama teman ketika pembelajaran berlangsung.

Etika kepedulian memandang perempuan memiliki kemampuan yang berbeda dengan laki-laki. Perempuan lebih mengedepankan tanggung jawab daripada hak yang dimiliki. Amelia menunjukkan tanggung jawab sebagai prioritasnya ketika memutuskan menjemput Norris daripada meninggalkannya karena tidak segera kembali ke kelas. Kejadian tersebut dapat dilihat pada kutipan di bawah ini

Sepuluh menit berlalu, Norris tetap tidak kembali. Anak-anak semakin ramai bermain. Suara berisik kami pasti terdengan hingga kelas sebelah.

Maya menatapku. Tatapannya menyiratkan apa kubilang.

"Aku akan menyusul Norris". Aku akhirnya berdiri, memutuskan melakukan sesuatu. Jangan sampai pak Bin kembali ke kelas dan menemukan keributan ini. (Liye,2017:86)

Kutipan di atas menunjukkan kepedulian Amelia terhadap tanggung jawabnya sebagai pembaca materi di kelas sebagai pengganti Pak Bin. Sebenarnya Amelia mempunyai hak untuk meninggalkan Norris dan melanjutkan membaca materi karena Norris belum kembali hingga sepuluh menit, tetapi Amelia memilih menjemput Norris daripada melanjutkan membaca materi karena hal tersebut merupakan tanggung jawabnya sebab memberi Norris izin ke kamar mandi.

Kepekaan etika yang ditunjukkan oleh Amelia merupakan teladan bagi siswa perempuan pendidikan dasar dalam menunjukkan kepedulian terhadap situasi-situasi etis. Pemilihan Amelia sebagai contoh dilandasi oleh karakteristik yang dimiliki oleh Amelia, yakni seorang perempuan dan bersekolah di jenjang sekolah dasar kelas tiga. Selain sebagai teladan, kepekaan etika yang ditunjukkan oleh Amelia juga dapat digunakan untuk latihan mengembangkan satu di antara komponen literasi moral.

\section{Penalaran Etis sebagai Landasan Kepedulian terhadap Situasi Etis}

Komponen dasar kedua yang harus dipenuhi agar menjadi individu yang moral literate adalah kemampuan memahami dan menilai fakta-fakta yang relevan dengan situasi-situasi etis. Kemampuan tersebut ditunjukkan oleh Amelia ketika menalar dan menilai situasi etis yang dihadapinya. Di antaranya ketika Amelia memberikan buku yang telah dibeli kepada Norris. Kejadian tersebut dapat dilihat pada kutipan di bawah ini

Aku tidak suka dengan perasaan ini, merasa bersalah. Sama ketika aku diam-diam merusak sikat gigi Kak Eli, lantas sepanjang malam sebelum 
ketahuan aku merasa tidak nyaman, merasa bersalah...Norris datang terlambat sesuai yang dijanjikan oleh pedagang buku dan majalah bekas. Apa salahku?

Tapi separuh hatiku yang lain berbisik, bukankah Norris sudah matimatian berusaha mendapatkan uang itu? Boleh jadi dia terlambat oleh keramaian, atau Bapaknya tidak mudah ditemukan sehingga Norris tidak bisa kembali tepat waktu? Itu fakta yang tidak bisa dipungkiri. (Liye,2017:153)

Kutipan di atas menunjukkan kemampuan Amelia dalam memahami dan menilai fakta tentang situasi yang dialami oleh dirinya dan Norris. Amelia memahami kondisi Norris yang berusaha secepat-cepatnya untuk mendapatkan uang agar dapat membeli buku pada pedagang buku dan majalah bekas. Amelia juga mampu menilai bahwa keterlambatan Norris kembali ke pedagang tersebut mungkin disebabkan oleh hal-hal yang sebenarnya tidak diingini oleh Norris.

Pemahaman dan penilaian etis yang dilakukan oleh Amelia menjadi landasan Amelia untuk mewujudkan kepeduliannya terhadap temannya, Norris. Penalaran etis yang baik menghasilkan realisasi kepekaan etika yang baik juga. Penalaran etis Amelia sebagai siswa perempuan yang masih berada di jenjang kelas 3 Sekolah Dasar dapat dijadikan panutan untuk siswa perempuan Pendidikan Dasar. Cara Amelia memahami dan menilai fakta dalam situasi etis dapat diselipkan oleh Guru dalam tema-tema tertentu yang berhubungan dengan beberapa kisah yang terdapat dalam novel Amelia karya Tere Liye.

\section{Imajinasi Moral sebagai Rencana Menghadapi Situasi Etis}

Selain kepekaan etika dan penalaran etis, hal yang harus dikembangkan agar menjadi manusia yang melek moral adalah imajinasi moral. Imajinasi moral dikembangkan untuk membayangkan kemungkinan-kemungkinan yang terjadi dalam situasi-situasi etis, sehingga mampu menentukan keputusan yang tepat untuk diambil. Bentuk imajinasi moral yang ditunjukkan oleh Amelia adalah rencana-rencananya untuk menyejahterakan kampung halamannya. Hal tersebut dapat dilihat pada kutipan di bawah ini

Inilah duniaku sekarang. Dan menjadi guru adalah cita-cita terbaik yang pernah kumiliki saat menatap wajah tulus Pak Bin dan senyum lapang Nek Kiba mengurus kami dulu. Aku memiliki teladan guru-guru terbaik dalam hidupku...maka, hari ini, tidak boleh ada keterbatasan di lembah ini. Tidak ada. Anak-anak lenbah berhak atas pendidikan terbaik. Aku akan memastikannya.

(Liye,2017:390-391)

Kutipan di atas menunjukkan kemampuan Amelia dalam mengembangkan rencana untuk memajukan pendidikan di kampung halamannya. Rencana tersebut yang mendorong Amelia berkuliah di luar negeri dan menyandang gelar $\mathrm{Ph}$. D untuk menghilangkan keterbatasan pendidikan di kampung halamannya. Imajinasi moral dalam hal ini dapat diartikan sebagai citacita dan harapan. Harapan dan cita-cita yang dimiliki oleh Amelia dapat dijadikan teladan bagi siswa perempuan Pendidikan Dasar. Rencana-rencana yang telah tertanam sejak dini mampu menghasilkan kekuatan pantang menyerah dalam menghadapi situasi-situasi etis tertentu.

\section{SIMPULAN}

Esensi dari tujuan pendidikan yang mengacu terhadap pembangun dan pengembang watak dianggap belum tercapai berdasarkan fakta-fakta yang telah disajikan sebelumnya. Tingkat moralitas anak-anak Indonesia sedang berada pada tahap kritis. Kontradiksi antara fakta sosial dan tujuan pendidikan itu sendiri yang mendasari pengembangan literasi moral perlu dilakukan.

Satu di antara pendekatan yang bisa digunakan untuk membangun generasi yang melek moral adalah karya sastra. Karya sastra sebagai penghibur sekaligus pengajar bisa menjadi suatu titik terang untuk membantu esensi dari tujuan pendidikan dapat tercapai. Novel Amelia karya Tere Liye mampu mendukung pembentukan siswa yang memiliki kemampuan literasi moral, khususnya siswa 
perempuan. Tokoh Amelia dalam novel tersebut menujukkan kepekaan etika, penalaran etis, dan imajinasi moral dengan prinsip-prinsip kepedulian yang tinggi, meskipun masih berada di jenjang kelas tiga Sekolah Dasar. Kepedulian tokoh Amelia dapat menjadi teladan bagi siswa perempuan Pendidikan Dasar dalam memenuhi esensi dasar tujuan pendidikan.

\section{DAFTAR PUSTAKA}

Bennett, Wliliam J., "Moral Literacy and The Formation of Character", Departement of Education, 1986.

Gilligan, Carol., "In a Different Voice: Psychological Theory and Women's Development., Harvard University Press, 1993.

Herman, Barbara., "Moral Literacy", Stanford University, 1997

Johnson, M., "Moral Imagination", University of Chicago Press, 1993.

Liye, Tere., "Amelia Serial Anak-anak Mamak", Republika, 2017.

Pahl, Kate., and Rowsell, Jennifer., "Literacy and Education", Paul Chapman Publishing, 2005.

Syahrul, Minawati., "Menanamkan Pendidikan Karakter kepada Siswa Melalui Sastra", pada Prosiding Konferensi Internasional HISKI Universitas Negeri Yogyakarta, 144-155 (2012).

Tuana, Nancy., "Conceptualizing Moral Literacy", Journal of Educational Administration 45 (4), 364-378 (2007).

Wellek, Rene., and Werren, Austin., "Teori Kesusastraan", Gramedia, 2016. 